Journal of Health Policy and Management (2017), 2(1):28-41

https://doi.org/10.26911/thejhpm.2017.02.01.03

\title{
Social Economic Equity in the Utilization of Hemodialysis among Patients with Chronic Renal Failure under National Health Insurance Plan at Dr. Moewardi Hospital, Surakarta
}

\author{
Kukuh Ardian'), Endang Sutisna Sulaeman'), Arief Suryono²) \\ ${ }^{1)}$ Masters Program in Public Health, Sebelas Maret University \\ 2)Faculty of Law, Sebelas Maret University
}

\begin{abstract}
Background: The health care reform promulgated by World Health Organization (WHO), namely Universal Health Coverage (UHC), aims to ensure that every citizen has access to affordable and equitable health care they need with good quality. The Indonesian National Health Insurance Plan has been implemented since January 1, 2014. However, anecdotal evidence indicates that there are some inequity concerns on the use of expensive medical care, such as renal hemodialysis. This study aimed to examine social economic equity in the utilization of hemodialysis among patients with chronic renal failure under the National Health Insurance (NHI, JKN) plan.

Subjects and Method: This study was analytic observational using cross-sectional design. This study was conducted at Dr. Moewardi Hospital, Surakarta, from March to April 2017. A sample of 120 patients with chronic renal failure was selected for this study by simple random sampling. The dependent variable was frequency of hemodialysis use. The independent variables were educational status, location of residence, family income, employment status (formal vs. informal), and membership status (beneficiary vs. non-beneficiary of government subsidy). The data were collected by questionnaire and were analyzed by path analysis.

Results: Higher frequency of hemodialysis use was directly associated with higher family income $(b=5.04 ; \mathrm{SE}=2.36 ; \mathrm{p}=0.033)$, distance $<20 \mathrm{~km}(\mathrm{~b}=-1.10 ; \mathrm{SE}=2.15 ; \mathrm{p}=0.610)$, working in informal sector $(b=3.84 ; \mathrm{SE}=3.05 ; \mathrm{p}=0.305)$, beneficiary of government subsidy $(b=-3.68 ; \mathrm{SE}=2.81$; $\mathrm{p}=0.190)$, longer duration of hemodialysis $(\mathrm{b}=0.39 ; \mathrm{SE}=0.08 ; \mathrm{p}<0.001)$, severe condition of illness $(b=46.11 ; \mathrm{SE}=2.42 ; \mathrm{p}<0.001)$, and living in urban area $(b=3.34 ; \mathrm{SE}=0.31 ; \mathrm{p}=0.147)$.

Conclusion: Higher frequency of hemodialysis use is directly affected by higher family income, distance $<20 \mathrm{~km}$, working in informal sector, beneficiary of government subsidy, longer duration of hemodialysis, severe condition of illness, and living in urban area.
\end{abstract}

Keywords: National Health Insurance, membership, hemodialysis, inequity

Correspondence: Kukuh Ardian. Masters Program in Public Health, Sebelas Maret University, Surakarta. Email: kukuh.ardph@gmail.com. Mobile: 082298148101.

\section{LATAR BELAKANG}

Negara yang masuk dalam kategori low and middle income countries (LMICs) melakukan reformasi sistem pelayanan kesehatan menuju Universal Health Coverage (UHC). Walaupun demikian pemahaman UHC belum sesuai, karena menjadikan pembentukan UHC masih sebagai tujuan akhir (Oliver et al., 2014). UHC yang dipromosikan World Health Organization (WHO) bertujuan agar masyarakat mendapatkan pelayanan kesehatan yang berkualitas, melindungi orang-orang dari pemiskinan kesehatan dan meningkatkan ekuitas kesehatan ke seluruh kelompok sosial ekonomi (Robertsonet et al., 2013). Pemerintah atau negara perlu mempertimbangkan tiga dimensi utama, yaitu penduduk sebagai penerima manfaat, package, dan proporsi subsidi publik untuk penyediaan layanan kesehatan (Evans and Etienne, 2010). 
Setelah resolusi World Health Assembly (WHA) pada pembiayaan kesehatan yang berkelanjutan untuk UHC, pilihan kebijakan yang akan diadopsi harus sesuai dengan konteks ekonomi, sosial budaya dan politik masing-masing negara (Glenister, 2003).

Indonesia menerapkan sistem kesehatan yang baru pada 1 Januari 2014.Sistem ini disebut Jaminan Kesehatan nasional (JKN) atau Asuransi Kesehatan Nasional (Aulia et al., 2016). JKN adalah wujud dari pelaksanaan UHC di Indonesia yang rencananya akan dilaksanakan secara penuh pada tahun 2019. Ada beberapa perbedaan antara asuransi kesehatan nasional lama dan yang baru. Dalam sistem lama, ada beberapa lembaga yang menyelenggarakan program asuransi kesehatan nasional. Ada Jamkesmas, Jamkesda dan Askes. Jamkesmas adalah lembaga yang menangani asuransi kesehatan bagi masyarakat miskin,

Jamkesda adalah lembaga yang menangani asuransi kesehatan bagi masyarakat miskin daerah. Jamkesda memberikan sumbangan tambahan untuk orang miskin jika dana dari Jamkesmas tidak cukup untuk menutupi biaya perawatan kesehatan di wilayah itu. Askes adalah lembaga yang melaksanakan program asuransi kesehatan bagi pegawai pemerintah (Raharjo, 2016). Undang-Undang No. 24 Tahun 2011 menetapkan, Jaminan Sosial Nasional diselenggarakan oleh suatu Badan Penyelenggara Jaminan Sosial (BPJS), yang terdiri atas BPJS Kesehatan dan BPJS Ketenagakerjaan. Khusus untuk JKN akan diselenggarakan oleh BPJS Kesehatan.

Sebagaimana dalam pelaksanaan program JKN di atas, maka kepesertaan bersifat wajib. Peserta adalah setiap orang, termasuk orang asing yang bekerja paling singkat 6 (enam) bulan di Indonesia, yang telah membayar iuran. Peserta JKN terdiri dari Peserta Penerima Bantuan Iuran (PBI) dan Peserta bukan Penerima Bantuan Iuran (Bukan PBI) Mandiri (tnp2k, 2016).

Pelaksanaan hemodialisis masih terpusat pada rumah sakit tipe A dan B yaitu 50\% padahal rumah sakit tipe A dan B mempunyai biaya klaim tertinggi di Indonesia Case Base Groups (INA-CBGS) ini menjadi salah satu faktor membengkaknya biaya klaim (ipdi, 2013). Berdasarkan data distribusi dan biaya klaim dalam kasus Rawat Jalan tingkat Lanjutan (RJTL). BPJS sampai kuartal ketiga 2015, kasus sistem saluran kemih sebesar 3,094,915 sebagai urutan ketiga tertinggi, tetapi menempati biaya lebih dari 3 triliun rupiah (PDPERSI, 2016).

Akses keperawatan kesehatan dalam perkembangan sejarah kebijakan kesehatan dan pelayanan kesehatan merupakan strategi kunci untuk pengurangan kemiskinan. Hal ini didasarkan pada interaksi dari faktor pertama permintaan dan faktor kedua persediaan yang dapat menentukan individuatau akses masyarakat terhadap pelayanan kesehatan. Kesediaan perorangan atau masyarakat untuk membayar biaya perawatan kesehatan. Ketersediaan penunjang pelayanan kesehatan untuk ketersediaan tenaga profesional kesehatan, fasilitas serta ketersediaan pasokan, seperti tempat tidur dan obat-obatan. Misalnya, dokter/ perawat untuk rasio pasien sangat penting dalam menentukan kualitas perawatan pasien di fasilitas kesehatan. Faktor ketiga, aksesibilitas geografis mengacu pada lokasi fisik dari fasilitas kesehatan sehubungan dengan lokasi pemakai pelayanan kesehatan.

Hasil penelitian yang telah dilakukan banyak yang menunjukkan bahwa faktorfaktor tersebut mempengaruhi perilaku dan berdampak pada tindakan masyarakat dalam memperoleh pelayanan kesehatan (Ensor dan Cooper, 2004; Kerber et al., 2007; Peters et al., 2008; Arthur, 2012; Ardian, 2014; Kerber et al., 2007) berpen- 
Journal of Health Policy and Management (2017), 2(1):28-41

https://doi.org/10.26911/thejhpm.2017.02.01.03

dapat bahwa jarak yang jauh, pengetahuan, kendala keuangan, transportasi yang buruk, dan perawatan kualitas yang buruk di fasilitas kesehatan merupakan hambatan serius membatasi akses ke perawatan bagi mereka yang membutuhkannya. Dengan kata lain, jarak ke fasilitas kesehatan dan biaya transportasiyang terkait lebih lanjut dapat membatasi akses masyarakat miskin terhadap pelayanan kesehatan.

Faktor aksesibilitas meliputi keuangan, geografis, dan ketersediaan pelayanan kesehatan menentukan perilaku mencari pelayanan kesehatan dan pertimbangan utama mereka ke akses ke perawatan kesehatan (rural health information, 2014).

Faktor-faktor ini membutuhkan perhatian karena mereka setuju dalam intervensi kebijakan terhadap kesehatan, pendidikan, lokasi pelayanan kesehatan, pendapatan, jenis pekerjaan, status kepersertaan dan metode pembayaran dokter terkait akses masyarakat belum tentu mencapai kesetaraan dalam pelayanan kepersertaan JKN memanfaatkan hemodialisis, tetapi dengan adanya JKN mungkin setidaknya membuat kesempatan yang sama untuk mendapatkan pelayanan kesehatan, sehingga meningkatkan keadilan sosial. Nerenz (2011) berpendapat, "Keadilan Sosial" membutuhkan tidak adanya dari perbedaan, tetapi lembaga yang menyelegarakan pelayanan harus mampu menghormati perbedaan kelompok tanpa penindasan". Keterbatasan sumber daya dan kendala anggaran menjadi jawaban untuk perencanaan kebijakan kesehatan yang partisipatif untuk memastikan pemerataan yang seimbang terkait health facilities (fasilitas kesehatan), projects (rencana) dan interventions (pelaksanaan).

Berdasarkan temuan tersebut maka peneliti ingin melakukan penelitian yang berjudul "Keadilan Sosial Ekonomi penggunaan hemodialisis pada pasien gagal gin- jal kronis jaminan kesehatan nasional di RSUD Dr. Moewardi”.

\section{SUBJEK DAN METODE \\ 1. Desain Penelitian}

Metode penelitian yang digunakan dalam penelitian ini adalah studi analytic observational dengan desain studi cross sectional. Waktu penelitian dilakukan pada bulan Maret-April 2017 di RSUD Dr. Moewardi, Provinsi Jawa Tengah.

\section{Populasi dan Sampling}

Populasi sasaran dalam penelitian ini adalah seluruh pasien hemodialisis di Surakarta. Sedangkan populasi sumber dalam penelitian ini yaitu pasien hemodialis di RSUDMoewardi.

Teknik sampling yang akan digunakan dalam penelitian ini yaitu simple random sampling. Teknik sampling ini mencuplik sampel secara acak, sehingga sampel memiliki peluang yang sama untuk terpilih menjadi subjek penelitian (Murti, 2013).

\section{Variabel Penelitian}

Variabel dependen adalah penggunaan hemodialisis. Variabel independen adalah status pendidikan, lokasi tempat tinggal, pendapatan keluarga, jenis pekerjaan, status kepersertaan, dan metode pembayaran kesehatan

\section{Definisi Operasional}

Definisi operasional dari lokasi desa/ kota yaitu suatu wilayah kerja lurah sebagai perangkat daerah kabupaten/ kota dalam wilayah kerja kecamatan. Jarak tempuh yaitu suatu wilayah kerja lurah sebagai perangkat daerah kabupaten/ kota dalam wilayah kerja kecamatan. Pendapatan keluarga yaitu penghasilan perkapita perbulan yang dihitung dari jumlah rata-rata pendapatan yang diterima keluarga baik tetap maupun tidak tetap setiap bulan dibagi dengan jumlah anggota keluarga, yang dinyatakan dalam rupiah. Status pekerjaan pasien yaitu kegiatan rutin yang dilakukan dalam upaya 
mendapatkan penghasilan untuk memenuhi kebutuhan. Metode kepersertaan pasien yaitu jenis Iuran BPJS yang dibayar pasien. Lama Hemodialisis yaitu lama penggunaan hemodialisis dalam satuan bulan. Keparahan yaitu jumlah frekuensi hemodialisis dalam satu minggu menentukan tingkat kerusakan ginjal dan pengunaan hemodialisis yaitu jumlah penggunaan layanan hemodialisis.

\section{Instrumen Penelitian}

Teknik pengumpulan data dilakukan dengan kuesioner sebagai instrumen penelitian. Instrumen ini berupa kuesioner tertutup. Sebelum responden mengisi kuesioner, peneliti menjelaskan terlebih dahulu maksud dan tujuan penelitian, menjelaskan cara pengisian kuesioner, menyampaikan tentang kerahasiaan identitas subjek penelitian dan memberikan hak kepada subjek penelitian jika ingin mengundurkan diri. Instrumen pada penelitian menggunakan kuesioner yang telah diuji validitas dan reliabilitas.

\section{Analisis Data}

Analisis data yang digunakan dalam penelitian ini yaitu path analysis (analisis jalur). Path analysis (analisis jalur) merupakan suatu bentuk terapan dari analisis multiregresi. Analisis ini menggunakan diagram jalur yang kompleks sehingga dapat menghitung besarnya pengaruh langsung dari setiap variabelbebas terhadap variabel terikat. Pengaruh dalam variabel dapat terlihat sebagai koefisien jalur (path coeficients) yang sebenarnya merupakan koefisien regresi yang sudah dibakukan.

Langkah-langkah dalam melakukan analisis data dengan menggunakan analisis jalur yaitu spesifikasi model, identifikasi model, estimasi parameter, dan respesifikasi model.

\section{A. Analisis Univariat}

Hasil penelitian yang telah dilakukan terhadap 120 subjek penelitian.

Tabel 1. Karakteristik subjek penelitian

\begin{tabular}{|c|c|c|c|}
\hline Karakteristik & & $\begin{array}{c}\text { Frekuensi } \\
\text { (n) }\end{array}$ & Presentase (\%) \\
\hline \multirow[t]{4}{*}{ Usia } & $<40$ Tahun & 41 & 34.2 \\
\hline & 41-50 tahun & 22 & 18.3 \\
\hline & 51-6o Tahun & 28 & 23.3 \\
\hline & $\geq 60$ Tahun & 29 & 24.2 \\
\hline \multirow[t]{6}{*}{ Pendidikan } & Tidak sekolah & 16 & 13.3 \\
\hline & SD & 17 & 14.2 \\
\hline & SMP & 33 & 27.5 \\
\hline & SMA & 38 & 31.7 \\
\hline & Diploma & 3 & 2.5 \\
\hline & Sarjana & 13 & 10.8 \\
\hline \multirow[t]{2}{*}{ Jenis kelamin } & Laki-laki & 60 & 50.0 \\
\hline & Perempuan & 60 & 50.0 \\
\hline \multirow[t]{2}{*}{ Lokasi tempat tinggal } & Desa & 43 & 35.8 \\
\hline & Kota & 77 & 64.2 \\
\hline \multirow[t]{2}{*}{ Status kepersertaan } & Bukan PBI & 99 & 82.5 \\
\hline & PBI & 21 & 17.5 \\
\hline \multirow[t]{2}{*}{ Pekerjaan } & Informal & 99 & 82.5 \\
\hline & Formal & 21 & 17.5 \\
\hline \multirow[t]{2}{*}{ Tingkat keparahan } & Ringan & 36 & 30.0 \\
\hline & Parah & 84 & 70.0 \\
\hline \multirow[t]{2}{*}{ Pendapatan } & $<$ Rp 2,000,000 & 49 & 40.8 \\
\hline & $\geq \operatorname{Rp} 2,000,000$ & 71 & 59.2 \\
\hline
\end{tabular}

Distribusi frekuensi karakteristik subjek penelitian berdasarkan usia, pendidikan, jenis kelamin, lokasi tempat tinggal, status kepersertaan, pekerjaan, tingkat keparahan dan 
Journal of Health Policy and Management (2017), 2(1):28-41

https://doi.org/10.26911/thejhpm.2017.02.01.03

pendapatan telah dilakukan uji statistik untuk melihat distribusi frekuensi.

Karakteristiksubjek penelitian dijelaskan pada Tabel 1 menunjukkan bahwa sebagian besar subjek penelitian berusia dibawah atau sama dengan 40 tahun yaitu sebanyak 41 Pasien (34.2\%), tingkat pendidikan sebagian besar tamatan SMA 38 pasien (31.7\%), jenis kelamin sebagian besar subjek penelitian yaitu laki-laki sebanyak 60 pasien (50.0\%) yang sebagian besar bertempat tinggal di kota sebanyak 77 pasien (64.2\%), dari keseluruhan subjek penelitian, sebagian besar merupakan pasien dengan status kepersertaan bukan PBI sebanyak 99 pasien (82.5\%). Berdasarkan pemeriksaan rekam medis sebagian besar subjek penelitian termasuk dalam kategori parah 84 pasien (70.0\%) yaitu pasien men- dapatkan diagnosis cuci darah lebih dari sekali, subjek penelitian pada hasil wawancara berdasarkan pendapatan $\geq \mathrm{Rp} 2,000$, ooo sebanyak 71 pasien (59.2\%).

\section{B. Analisis Bivariat}

Tabel 2 menunjukkan hasil analisis bivariat tentang pengaruh satu variabel independen terhadap satu variabel dependen. Variabel independen pada penelitian ini adalah tingkat pendidikan, lokasi tempat tinggal, status kepersertaan BPJS, jenis pekerjaan, lama hemodialisis, tingkat keparahan penyakit, pendapatan keluarga dan jarak sedangkan variabel dependen pada penelitian ini adalah Frekuensi penggunaan hemodialisis per tahun. Metode yang digunakan adalah uji pearson dengan taraf kepercayaan $95 \%$ (nilai $\mathrm{p}=0.05$ ).

Tabel 2. Analisis bivariat variabel Independen terhadap frekuensi penggunaan hemodialisis pertahun.

\begin{tabular}{lcc}
\hline \multicolumn{1}{c}{ Variabel Independen } & Pearson correlation (r) & p \\
\hline Tingkat Pendidikan & 0.29 & 0.002 \\
Lokasi Tempat Tinggal & 0.07 & 0.432 \\
Status Kepesertaan BPJS & -0.12 & 0.195 \\
Jenis Pekerjaan Pasien & -0.05 & 0.604 \\
Lama Hemodialisis & 0.38 & 0.000 \\
Tingkat Keparahan Penyakit & 0.86 & 0.000 \\
Pendapatan Keluarga & 0.11 & 0.233 \\
Jarak & -0.05 & 0.603 \\
\hline
\end{tabular}

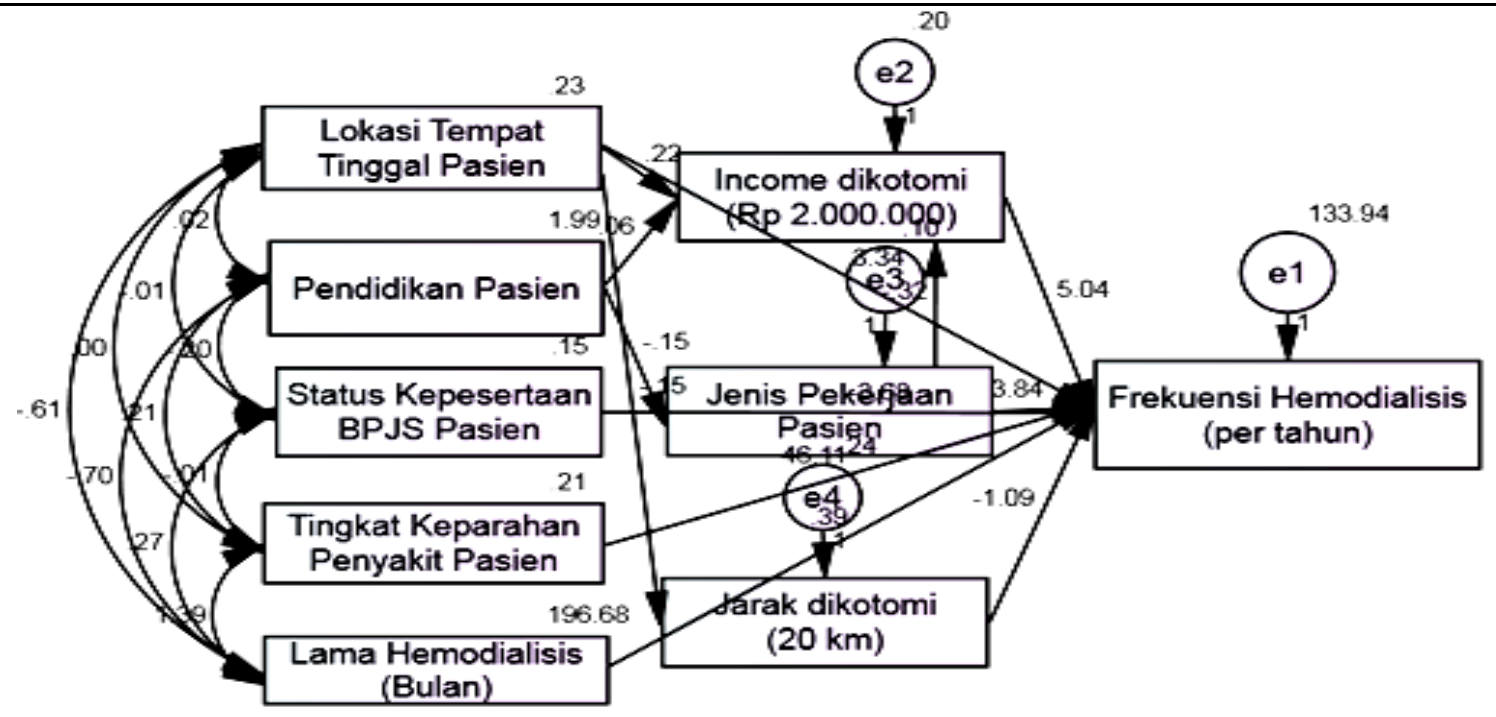

Gambar 1. Model struktural analisis jalur frekuensi penggunaan hemodialisis per tahun dengan estimasi 
Tabel 3. Hasil analisis jalur (path analysis)

\begin{tabular}{|c|c|c|c|c|c|}
\hline $\begin{array}{l}\text { Variabel } \\
\text { Dependen }\end{array}$ & $\begin{array}{c}\text { Variabel } \\
\text { Independen }\end{array}$ & $\begin{array}{l}\text { Koefisien jalur } \\
\text { unstandardized } \\
\text { (b) }\end{array}$ & SE & $\mathbf{p}$ & $\begin{array}{c}\text { Koefisien jalur } \\
\text { standardized (beta) }\end{array}$ \\
\hline Frekuensi HD & $\begin{array}{l}\text { — Pendapatan keluarga } \\
(\geq \mathrm{Rp} 2,000,000)\end{array}$ & 5.04 & 2.36 & 0.033 & 0.96 \\
\hline Frekuensi HD & $\leftarrow$ Jarak $(\mathrm{Km})$ & -1.10 & 2.15 & 0.610 & -0.02 \\
\hline Frekuensi HD & $\leftarrow$ Pekerjaan (Informal) & 3.84 & 3.05 & 0.208 & 0.06 \\
\hline Frekuensi HD & $\begin{array}{l}\leftarrow \text { Status kepersertaan } \\
(\text { Bukan PBI) }\end{array}$ & -3.68 & 2.81 & 0.190 & -0.05 \\
\hline Frekuensi HD & $\leftarrow$ Lama HD (Bulan) & 0.39 & 0.08 & $<0.001$ & 0.21 \\
\hline Frekuensi HD & $\leftarrow$ Keparahan & 46.11 & 2.42 & $<0.001$ & 0.82 \\
\hline Frekuensi HD & $\leftarrow$ Tempat Tinggal (Kota) & 3.34 & 0.31 & 0.147 & 0.06 \\
\hline Pekerjaan & $\leftarrow$ Pendidikan & -0.15 & 0.02 & 0.001 & -0.55 \\
\hline Pendapatan & $\leftarrow$ Pekerjaan (Informal) & -0.32 & 0.13 & 0.013 & -0.25 \\
\hline Pendapatan & $\leftarrow$ Tempat tinggal (Kota) & 0.22 & 0.09 & 0.009 & 0.22 \\
\hline Pendapatan & $\leftarrow$ Pendidikan & 0.06 & 0.04 & 0.108 & 0.16 \\
\hline Jarak & $\leftarrow$ Tempat tinggal (Kota) & -0.15 & 0.09 & 0.118 & -0.14 \\
\hline \multicolumn{6}{|l|}{ Model Fit } \\
\hline $\operatorname{CMIN}\left(x^{2}\right)=15.972$ & $\mathrm{p}=0.315(>0.05)$ & & & & \\
\hline $\mathrm{CFI}=0.993$ & $(\geq 0.90)$ & & & & \\
\hline $\mathrm{NFI}=0.947$ & $(\geq 0.90)$ & & & & \\
\hline $\mathrm{GFI}=0.973$ & $(\geq 0.90)$ & & & & \\
\hline RMSEA $<0.034$ & $(\leq 0.208)$ & & & & \\
\hline
\end{tabular}

\section{Analisis Multivariat}

Gambar 1 menunjukkan model struktural setelah dilakukan estimasi menggunakan program AMOS, sehingga didapatkan nilai pada gambar tersebut. Indikator yang menunjukkan goodness of fit measure (pengukuran kecocokan model), didapatkan hasil index fit (indeks kecocokan) CMIN sebesar 9.166 dengan nilai $\mathrm{p}=0.315>0.05$; $\mathrm{NFI}=$ $0.947>0.90 ; \mathrm{CFI}=0.993>0.90$; $\mathrm{RMSEA}=$ $0.034<0.08$ yang berarti bahwa model empirik tersebut memenuhi kriteria yang ditentukan dan dinyatakan sesuai dengan data empirik.

Tabel 3 menunjukkan bahwa setiap peningkatan satu unit pendapatan keluarga akan meningkatkan frekuensi penggunaan hemodialisis sebesar 5.04 unit $(b=5.04$, $\mathrm{SE}=2.36, \quad \mathrm{p}=0.033)$. Setiap peningkatan satu unit jarak akan menurunkan frekuensi penggunaan hemodialisis sebesar 1.10 unit $(b=-1.10, S E=2.15, p=0.610)$.

Setiap peningkatan satu unit jenis pekerjaan akan meningkatkan frekuensi penggunaan hemodialisis sebesar 3.84 unit $(b=3.84, \quad S E=3.05, p=0.305)$. Setiap peningkatan satu unit status kepesertaan akan menurunkan frekuensi penggunaan hemodialisis sebesar 3.68 unit $(b=-3.68$, $\mathrm{SE}=2.81, \mathrm{p}=0.190$ ).

Setiap peningkatan satu unit lama hemodialisis akan meningkatkan frekuensi penggunaan hemodialisis sebesar 0.39 unit $(b=0.39, S E=0.208, p<0.001)$. Setiap peningkatan satu unit tingkat keparahanan akan menaikan frekuensi penggunaan hemodialisis sebesar 46.11 unit $(b=46.11, \mathrm{SE}=$ 2.42, $\mathrm{p}<0.001$ ).

Setiap peningkatan satu unit lokasi tempat tinggal akan meningkatkan frekuensi penggunaan hemodialisis sebesar 3.34 unit $(b=3.34, S E=0.31, p=0.147)$. Setiap peningkatan satu unit tingkat pendidikan akan menurunkan status pekerjaan sebesar 0.15 unit $(b=-0.15, \mathrm{SE}=0.02, \mathrm{p}=0.001)$.

Setiap peningkatan satu unit jenis pekerjaan akan menurunkan pendapatan keluarga sebesar 0.32 unit $(b=-0.32, \mathrm{SE}=$ $0.13, p=0.013)$. Setiap peningkatan satu unit lokasi tempat tinggal akan mening- 
Journal of Health Policy and Management (2017), 2(1):28-41

https://doi.org/10.26911/thejhpm.2017.02.01.03

katkan pendapatan keluarga sebesar 0.22 unit $(b=0.22, S E=0.09, p=0.009)$.

Setiap peningkatan satu unit tingkat Pendidikan akan meningkatkan pendapatan keluarga sebesar 0.06 unit $(b=0.06$, $\mathrm{SE}=0.04, \mathrm{p}=0.108$ ). Setiap peningkatan satu unit lokasi tempat tinggal akan menurunkan jarak sebesar 0.15 unit $(b=-0.15$, $\mathrm{SE}=0.09, \mathrm{p}=0.118)$.

\section{PEMBAHASAN}

\section{Pendapatan keluarga terhadap fre- kuensi penggunaan hemodialisis}

Hasil penelitian menunjukkan bahwa terdapat pengaruh pendapatan keluarga terhadap frekuensi penggunaan hemodialisis. Berdasarkan nilai koefisien yang didapat bahwa pendapatan keluarga berpengaruh positif terhadap frekuensi penggunaan hemodialisis.

Berdasarkan teori ekonomi kelompok yang paling kita kenal adalah keluarga. Gagasan keluarga sangat luas dan beragam, keluarga didefinisikan sebagai dua atau lebih orang yang memiliki hubungan darah, perkawinan atau adopsi yang hidup bersama. Pendapat lain menunjukkan bahwa sebuah unit keluarga biasanya merupakan keluarga yang lengkap, terdiri dari tiga generasi yang hidup bersama dan yang kerap terjadi tidak hanya kakek dan nenek, tapi juga paman, bibi, keponakan, dan kerabat lainnya. Dalam keluarga, keputusan untuk memenuhi kebutuhan hidup biasanya dilakukan oleh kepala keluarga, atau pencari nafkah. Anggota keluarga yang lain hanya mengikuti apa yang kepala keluarga ingin memutuskan. (Geyer, S. 2011).

Hal ini sejalan dengan teori ekonomi mikro tentang permintaan (demand) jasa pelayanan kesehatan menyebutkan bahwa harga berbanding terbalik dengan jumlah permintaan jasa pelayanan kesehatan. Teori ini mengatakan bahwa jika jasa pelayanan kesehatan merupakan normal good, makin tinggi pendapatan keluarga maka makin besar demand terhadap jasa pelayanan kesehatan tersebut. Sebaliknya jika jenis jasa pelayanan kesehatan tersebut merupakan inferior good, meningkatnya pendapatan keluarga akan menurunkan demand terhadap jenis jasa pelayanan kesehatan tersebut.

Berdasarkan hasil penelitian ini menunjukkan bahwa terdapat pengaruh pendapatan keluarga terhadap frekuensi penggunaan hemodialisis menunjukkan adanya pengaruh yang signifikan. Hal ini dikarenakan jika jasa pelayanan kesehatan merupakan normal good, makin tinggi pendapatan keluarga maka makin besar permintaan terhadap jasa pelayanan kesehatan tersebut.

Hasil penelitian ini sejalan dengan studi yang dilakukan oleh Kotler dan Andersen, 1995 demand (permintaan) adalah keinginan yang disertai dengan daya beli. Menurut, permintaan adalah keinginan terhadap produk spesifik yang didukung oleh kemampuan dan kesediaan untuk membeli. Demand atau permintaan adalah jumlah dari suatu barang yang mau dan mampu dibeli pada berbagai kemungkinan harga, selama jangka waktu tertentu, dengan anggapan berbagai hal lain tetap sama (ceteris paribus). Mau dan mampu di sini memiliki arti betapapun orang berkeinginan atau membutuhkan sesuatu, kalau ia tidak mempunyai uang atau tidak bersedia mengeluarkan uang sebanyak itu untuk membeli, maka keinginan tersebut belum disebut permintaan. Namun ketika keinginan atau kebutuhan disertai dengan kemauan dan kemampuan untuk membeli dan didukung oleh uang yang cukup untuk membayar maka akan disebut permintaan. Dengan demikian permintaan adalah kebutuhan dan keinginan yang didukung oleh daya beli. 
Permintaan (demand) pelayanan kesehatan adalah pelayanan yang sesungguhnya dibeli oleh customer pelayanan kesehatan, dalam hal ini adalah pasien. Permintaan tersebut dipengaruhi oleh pendapat medis dari dokter, dan juga faktor lain seperti pendapatan dan harga obat. Model dari Cooper Posnett (1988) dalam Palutturi (2005), permintaan (demand) pelayanan kesehatan merupakan keinginan untuk lebih sehat diwujudkan dalam perilaku mencari pertolongan tenaga kedokteran. Jadi dapat disimpulkan bahwa, permintaan (demand) pelayanan kesehatan adalah pelayanan kesehatan yang dibutuhkan dan diinginkan oleh pasien yang disertai juga dengan daya beli yang dimiliki oleh pasien tersebut.

Berdasarkan hal tersebut maka dapat disimpulkan bahwa terdapat pengaruh positif antara pendapatan keluarga terhadap frekuensi penggunaan hemodialisis, dengan demikian hasil penelitian ini sejalan dengan penelitian di atas.

\section{Pengaruh jarak terhadap frekuensi penggunaan hemodialisis}

Hasil penelitian menunjukkan bahwa terdapat pengaruh terhadap frekuensi penggunaan hemodialisis. Berdasarkan nilai koefisien yang didapat bahwa jarak berpengaruh negatif terhadap frekuensi penggunaan hemodialisis.

Secara umum jarak adalah letak wilayah berdasarkan standar geografis yang berhubungan dengan keterjangkauan tempat dan waktu. Keterjangkauan tempat berhubungan dengan tempat dan lokasi sarana pelayanan kesehatan dan tempat tinggal pasien dapat diukur dari jarak, waktu dan biaya perjalanan. Tempat tinggal pasien dengan pusat pelayanan kesehatan yang diukur dalam radius kilometer Amran Razak (2000) dalam Haeruddin (2007).

Konsep jarak tempat tinggal merupakan salah satu faktor yang mempengaruhi perilaku seseorang dalam melakukan suatu kegiatan. Semakin jauh jarak antara tempat tinggal dengan tempat kegiatan akan semakin menurunkan motivasi seseorang dalam melakukan aktivitas. Sebaliknya semakin dekat jarak tempat tinggal dengan tempat kegiatan dapat meningkatkan usaha.Pengaruh jarak tempat tinggal dengan tempat kegiatan tak terlepas dari adanya besarnya biaya yang digunakan dan waktu yang lama. Hal tersebut dalam penelitian ini tidak berlaku jika kesadaran masyarakat akan pentingnya kesehatan yang tinggi, menjadikan jarak antara rumah tinggal dan tempat pelayanan kesehatan tidak mempengaruhi perilaku mereka.

Hal ini didukung mutu pelayanan kesehatan mempunyai beberapa sudut pandang salah satunya yaitu akses pelayanan kesehatan adalah kemudahan program jaminan atau menjangkau pelayanan yang disediakan baik secara geografis, dimana akses berhubungan dengan transportasi, jarak dan lama perjalanan. Dengan demikian letak pelayanan kesehatan dapat dijangkau oleh masyarakat yang membutuhkannya.

Berdasarkan hal tersebut maka dapat disimpulkan bahwa terdapat pengaruh negatif jarak terhadap frekuensi penggunaan hemodialisis. Dengan demikian hasil penelitian ini sejalan dengan penelitian di atas.

\section{Pengaruh status pekerjaan terha- dap frekuensi penggunaan hemo- dialisis}

Hasil penelitian menunjukkan bahwa terdapat pengaruh positif status pekerjaan terhadap frekuensi penggunaan hemodialisis. Berdasarkan nilai koefisien yang didapat bahwa status pekerjaan berpengaruh positif terhadap frekuensi penggunaan hemodialisis.

Pekerjaan seseorang juga mempengaruhi pola konsumsi. Dalam hal mempengaruhi keputusan melakukan sesuatu salah satu faktor nya adalah faktor individu yang 
Journal of Health Policy and Management (2017), 2(1):28-41

https://doi.org/10.26911/thejhpm.2017.02.01.03

di dalamnya keputusan juga dipengaruhi oleh karakteristik pribadi seperti umur dan tahap siklus hidup, pekerjaan, situasi ekonomi, gaya hidup, kepribadian, dan konsep diri (Kotler dan Amstrong, 2011).

Di Indonesia, jenis pekerjaan sering dibedakan dengan pekerja sektor formal dan pekerja sektor informal. Dengan adanya kondisi jenis pekerjaan yang beragam, tentu mempengaruhi kebutuhan dan keinginan yang sangat luas dan bervariasi pula.

Berdasarkan hal tersebut maka dapat disimpulkan bahwa terdapat pengaruh positif antara status pekerjaan terhadap frekuensi penggunaan hemodialisis, dengan demikian hasil penelitian ini sejalan dengan penelitian di atas.

4. Pengaruh status kepersertaan terhadap frekuensi penggunaan hemodialisis

Hasil penelitian menunjukkan bahwa terdapat pengaruh negatif status kepersertaan terhadap frekuensi penggunaan hemodialisis.

Hasil penelitian ini sejalan dengan penelitian yang dilakukan oleh Rattu et al (2015) mengenai Perbedaan Kualitas Pelayanan Keperawatan Terhadap Pasien Penerima Bantuan Iuran dan Pasien Bukan Penerima Bantuan Iuran. Hasil penelitian bahwa pelayanan yang diberikan kepada setiap pasien adalah sama tanpa memandang status pasien sebagai penerima bantuan atau bukan, sehingga pasien dapat menerima haknya sebagai pasien sesuai dengan undang-undang yang berlaku.

Dalam hal ini peneliti menyadari bahwa peran BPJS sangatlah penting sebagai penjamin kesehatan yang berkeadilan yang membantu pasien hemodialisis, dimana pasien hemodialisis di rumah sakit Moewardi yang biayanya ditanggung secara penuh PBI maupun bukan PBI sebagai pasien kelas 2 sama rata hal ini menjadikan kemudahan akses program jaminan men- jadi salah satu faktor penentu pemanfaatan pelayanan kesehatan.

Berdasarkan hal tersebut maka dapat disimpulkan bahwa terdapat pengaruh positif status kepersertaan terhadap frekuensi penggunaan hemodialisis dengan demikian hasil penelitian ini sejalan dengan penelitian di atas.

\section{Pengaruh lama hemodialisis ter- hadap frekuensi penggunaan hemo- dialisis}

Hasil penelitian menunjukkan bahwa terdapat pengaruh lama hemodialisis terhadap frekuensi penggunaan hemodialisis. Lama hemodialisis memiliki pengaruh positif terhadap frekuensi penggunaan hemodialisis.

Efek yang positif terhadap penyakit akan membuat pasien lebih mudah beradaptasi dan penerimaan terhadap penyakit yang diderita. Adaptasi yang baik akan sangat mempengaruhi proses hemodialisis yang dijalani pasien termasuk kepatuhan pasien dalam menjalani hemodialisis. Pasien yang sudah beradaptasi terhadap penyakitnya akan mempengaruhi ideal diri terhadap penyakit yang dideritanya sehingga pasien akan mengalami penurunan stres psikologis secara signifikan dan kepatuhan yang baik. Hal ini menyebabkan pasien menjadi lebih tenang terhadap kondisi kesehatannya. Hal ini sesuai dengan penelitian Moskovitz et al (1999) yang menyatakan bahwa koping yang adaptif akan mempengaruhi kualitas hidup pasien.

Selain itu menurut Ramirez et al (2011) kondisi stres psikologis ini akan sangat dipengaruhi oleh koping religius pasien dan akan mempengaruhi kualitas hidup pasien. Kondisi masyarakat Indonesia yang beragama membuat kebanyakan pasien hemodialisis mempunyai koping religius yang positif.

Hemodialisis mereka lakukan dengan senang hati dan menganggap proses ter- 
sebut sebagai rekreasi spiritual. Hal ini juga sejalan dengan Berman et al (2004) yang menyatakan bahwa religiusitas seseorang yang menjalani hemodialisis sangat berkaitan dengan peningkatan kepuasan hidup pasien.

Berdasarkan hal tersebut maka dapat disimpulkan bahwa terdapat pengaruh positif lama hemodialisis terhadap frekuensi penggunaan hemodialisis, dengan demikian hasil penelitian ini sejalan dengan penelitian di atas.

\section{Pengaruh keparahan terhadap fre- kuensi penggunaan hemodialisis}

Hasil penelitian menunjukkan bahwa terdapat pengaruh positif secara langsung terhadap frekuensi penggunaan hemodialisis.

Hal ini sesuai dengan penelitian yang menunjukkan bahwa seseorang dengan dukungan sosial yang baik walaupun mempunyai tingkat gangguan kesehatan yang rendah. Dukungan sosial dapat bermanfaat bagi kesehatan walau belum diketahui secara pasti, namun dukungan sosial dapat menurunkan tingkat stres (Kornblith et al, 2001), membuat lebih terpenuhinya kebutuhan pasien, akses yang lebih baik terhadap layanan kesehatan, meningkatkan status psikososial, status nutrisi, dan peningkatan sistem imun (Patel et al., 2008).

Pasien CKD yang menjalani terapi hemodialisis mempunyai perubahan pola hidup yang sangat signifikan. Proses adaptasiyang mereka jalani pada saat awal menjalani proses hemodialisis adalah proses yang sangat berat. Dalam hal ini menurut peneliti bahwa motivasi untuk mencapai kualitas hidup yang lebih baik dibutuhkan faktor keluarga dan status kesehatan yang mendukung.

Berdasarkan hal tersebut maka dapat disimpulkan bahwa terdapat pengaruh keparahan terhadap frekuensi penggunaan hemodialisis. penelitian ini sejalan dengan penelitian di atas.

\section{Pengaruh lokasi tempat tinggal ter- hadap frekuensi penggunaan hemo- dialisis}

Hasil penelitian menunjukkan bahwa terdapat pengaruh secara langsung dan bernilai positif lokasi tempat tinggal terhadap frekuensi penggunaan hemodialisis.

Permintaan (demand) pelayanan kesehatan adalah Pelayanan yang sesungguhnya dibeli oleh customer pelayanan kesehatan, dalam hal ini adalah pasien. Permintaan tersebut dipengaruhi oleh pendapat medis dari dokter, dan juga faktor lain seperti pendapatan dan harga obat. Model dari Cooper Posnett (1988) dalam Palutturi (2005), permintaan pelayanan kesehatan merupakan keinginan untuk lebih sehat diwujudkan dalam perilaku mencari pertolongantenagakedokteran. Jadi dapat disimpulkan bahwa, permintaan masyarakat kota yang tinggi terhadap pelayanan kesehatan sesuai dengan yang dibutuhkan dan diinginkan oleh pasien perkotaan yang disertai juga dengan daya beli, pengetahuan yang lebih dimiliki oleh pasien perkotaan dibanding pasien pedesaan.

Berdasarkan hal tersebut maka dapat disimpulkan bahwa terdapat pengaruh positif secara langsung lokasi tempat tinggal terhadap frekuensi penggunaan hemodialisis.

\section{Pengaruh Pendidikan terhadap pe- kerjaan}

Hasil penelitian menunjukkan bahwa terdapat pengaruh negatif pendidikan terhadap status pekerjaan.

Pendidikan sangatlah penting tidak hanya untuk memahami dan menyadari hal tersebut saja. Namun pendidikan juga sangat penting untuk melangkah menuju prospek ke depannya, seperti dalam masalah mata pencaharian, terutama dalam pencarian pekerjaan bagi masyarakat. Pen- 
Journal of Health Policy and Management (2017), 2(1):28-41

https://doi.org/10.26911/thejhpm.2017.02.01.03

didikan yang tinggi akan mempengaruhi mata pencahariannya, semakin tinggi pendidikan maka pekerjaan yang akan diperoleh akan semakin tinggi pula tingkatannya. Suroto (1992) dimana banyak pula terdapat pekerja yang tidak harus dengan mengenyam dunia pendidikan, ada pula pekerja yang hanya mengenyam dunia pendidikan tidak sampai selesai. Mereka yang tidak memiliki pendidikan yang tinggi biasanya bermata pencaharian sebagai maupun bekerja sebagai buruh bangunan. Status pekerjaan juga dipengaruhi situasi sehat dan sakit yang dahulu berkeja menjadi tidak berkerja.

Berdasarkan hal tersebut maka dapat disimpulkan bahwa terdapat pengaruh negatif pendidikan terhadap status pekerjaan, dengan demikian hasil penelitian ini sejalan dengan penelitian di atas.

9. Pengaruh status pekerjaan terhadap pendapatan keluarga

Hasil penelitian menunjukkan bahwa terdapat pengaruh negatif status pekerjaan terhadap pendapatan.

Status pekerjaan dalam masyarakat Indonesia dibagi menjadi dua sektor, yaitu sektor formal dan informal dalam kaitan pendapatan keluarga tidak bisa dipengaruhi, karena pendapatan keluarga dipengaruhi oleh banyak faktor khususnya status ekonomi kekerabatan yang mendukung pendapatan keluarga.

Berdasarkan hal tersebut maka dapat disimpulkan bahwa terdapat pengaruh negatif antara status pekerjaan terhadap pendapatan keluarga.

\section{Pengaruh lokasi tempat tinggal terhadap pendapatan keluarga}

Hasil penelitian menunjukkan bahwa terdapat pengaruh positif lokasi tempat tinggal terhadap pendapatan.

Masyarakat desa memiliki pendapatan yang tidak besar. Sebab kebanyakan dari mereka memiliki mata pencaharian di bi- dang agraria. Kekayaan di desa juga tidak hanya diukur dari berapa uang yang mereka miliki namun dari berapa jumlah ternak yang mereka punya. Ini adalah suatu dampak dari kurangnya teknologi di desa. Masyarakat desa kebanyakan menyimpan uangnya di rumah, atau di celengan. Mereka belum mengenal lebih dalam tentang fungsi dari bank. Atau bahkan ada yang belum mengenal bank sama sekali. Meski ada yang sudah menabung di koperasi, namun belum semua melakukannya. Tingkat ekonomi tentu berpengaruh pada tingkat kesejahteraan. Dengan pendapatan yang hanya cukup untuk memenuhi kebutuhan seharihari, mereka sulit untuk mengembangkan diri ke tingkat yang lebih tinggi, seperti menyekolahkan anaknya sampai ke universitas, atau membeli modal untuk mengembangkanusaha mereka. Mereka juga kurang mampu membeli fasilitas penunjang seperti transportasi yang lebih efisien (mobil, motor, di desa masih dianggap sebagai barang mewah).

Di kota, tingkat ekonomi bervariasi. Ada yang miskin sekali dan ada yang sangat kaya raya. Kebanyakan orang-orang yang berada di bawah garis kemiskinan adalah akibat urbanisasi. Walaupun begitu, masyarakat kota memiliki tingkat kesejahteraan yang lebih tinggi di bidang ekonomi. Sebab dengan pengetahuan dan tingkat pendidikan yang lebih tinggi, mereka dapat lebih mengembangkan dirinya. Bahkan sekarang dengan teknologi internet, mereka bisa membuka usaha sendiri, bahkan meraup keuntungan sampai berjuta-juta rupiah setiap bulannya.

Berdasarkan hal tersebut maka dapat disimpulkan bahwa terdapat pengaruh positif lokasi tempat tinggal terhadap pendapatan keluarga. 


\section{Pengaruh Pendidikan terhadap pendapatan keluarga}

Hasil penelitian menunjukkan bahwa terdapat pengaruh positif pendidikan terhadap pendapatan keluarga

Di kota, tingkat ekonomi bervariasi. Ada yang miskin sekali dan ada yang sangat kaya raya. Kebanyakan orang-orang yang berada di bawah garis kemiskinan adalah akibat urbanisasi. Walaupun begitu, masyarakat kota memiliki tingkat kesejahteraan yang lebih tinggi di bidang ekonomi. Sebab dengan pengetahuan dan tingkat pendidikan yang lebih tinggi, mereka dapat lebih mengembangkan dirinya.

Penelitian ini didukung oleh wahyuni dan monica, 2016 dimana faktor pendidikan merupakan faktor penting dalam investasi sumber daya manusia. Pendidikan juga diharapkan dapat meningkatkan pendapatan serta menurunkan ketimpangan pendapatan keluarga baik di kota maupun di desa.

Berdasarkan hal tersebut maka dapat disimpulkan bahwa terdapat pengaruh positif pendidikan terhadap pendapatan keluarga.

\section{Pengaruh lokasi tempat tinggal terhadap jarak}

Hasil penelitian menunjukkan bahwa terdapat pengaruh negatif lokasi tempat tinggal terhadap jarak.

Permintaan (demand) pelayanan kesehatan adalah pelayanan yang sesungguhnya dibeli oleh customer pelayanan kesehatan, dalam hal ini adalah pasien. Permintaan tersebut dipengaruhi oleh pendapat medis dari dokter, dan juga faktor lain seperti pendapatan dan harga obat. Model dari Cooper Posnett (1988) dalam Palutturi (2005), permintaan pelayanan kesehatan merupakan keinginan untuk lebih sehat diwujudkan dalam perilaku mencari pertolongan tenaga kedokteran. Jadi dapat disimpulkan bahwa, permintaan (demand) masyarakat kota yang tinggi terhadap pela- yanan kesehatan sesuai dengan yang dibutuhkan dan diinginkan oleh pasien perkotaan yang disertai juga dengan daya beli, pengetahuan yang lebih dimiliki oleh pasien perkotaan dibanding pasien pedesaan.

Berdasarkan hal tersebut maka dapat disimpulkan bahwa terdapat pengaruh negatif lokasi tempat tinggal terhadap jarak, dengan demikian hasil penelitian ini sejalan dengan penelitian diatas.

Berdasarkan hasil penelitian, dapat disimpulkan bahwa frekuensi penggunaan hemodialisis dipengaruhi oleh pendapatan keluarga, jarak, jenis pekerjaan, status kepersertaan, lama hemodialisis, tingkat keparahan, dan lokasi tempat tinggal. Pendidikan dipengaruhi oleh pekerjaan. Pekerjaan dipengaruhi oleh pendapatan. Tempat tinggal dipengaruhi oleh pendapatan. Pendidikan dipengaruhi oleh pendapatan. Tempat tinggal dipengaruhi oleh jarak.

\section{DAFTAR PUSTAKA}

Amirullah (2002). Perilaku Konsumen, edisi pertama, cetakan pertama, Graha Ilmu, Yogyakarta.

Andersen RM (1995). Revisiting the behavioral model and access to medical care: does it matter? Journal of Health and Social Behaviour 36: 1-10.

Ardian K (2014). Analisis Utilisasi Pelayanan Rawat Inap Pasien BPJS PBI Di Rsud Kota Semarang. Available at: http://eprints.undip.ac.id/44742/1/5 089.pdf (Accessed 3 November 2016).

ArthurE(2012). Wealth And Antenatal Care Use: Implications For Maternal Health Care Utilisation In Ghana. Health Economics Review 2(1) 14.doi:10.11 86/2191-1991-2-14 Aryeetey, G. C., Jehu-Appiah.

Aulia S, Supriadi S, Sari DK, Mutiha A (2016). 'Cost Recovery Rate Program Jaminan Kesehatan Nasional BPJS 
Kesehatan', Study of Accounting 8(2). doi: 10.15408/akt.v8i2.2767.

Berman, Elisheva (2004). Religiosity in a Hemodialysis Population and Its relationship to Satisfaction With Medical Care, Satisfaction With Life and Adherence. American Journal of Kidney Disease 44(3): 488-497.

Dahlan MS (2009). Statistik untuk Kedokteran dan Kesehatan. Jakarta: Salemba Medika.

Ensor T, Cooper S (2004). Overcoming Barriers to Health Service Access: Influencing The Demand Side. Health Policy And Planning 19(2): 69-79. doi:10.1093/heapol/czhoo9.

Evans DB, Etienne C (2010). 'Health Systems Financing And The Path To Universal Coverage', Bulletin Of The World Health Organization, 88(6): 402-402. doi: 10.2471/blt.10.08741.

Glenister H (2003). 'Managing Projects In Health And Social Caremanaging Projects In Health And Social Care', Nursing Standard, 17(43): 28-28. doi: 10.7748/ns2003.07.17.43.28.b246.

Grauwin S, Szell M, Sobolevsky S, Hövel P, Simini F, Vanhoof M, Smoreda Z, Barabási A, Ratti C (2017). "Identifying and modeling the structural discontinuities of human interactions", Scientific Reports (Nature Publisher Group),7: 46677.

Haeruddin (2007). Analisis Permintaan Jasa Pelayanan Kesehatan pada Rumah Sakit Syekh Yusuf Kabupaten Gowa. Makassar: Fakultas Ekonomi Universitas Hasanuddin.

Hastono (2009). Statistik Kesehatan. Jakarta: Rajawali Press.

Hutapea, Tahan P (2009). Faktor-faktor yang Mempengaruhi Permintaan (Demand) Masyarakat Terhadap Pemilihan Kelas Perawatan Pada Rumah sakit Umum Dr.Syaiful Malang, Jawa
Timur. Jurnal Manajemen Pelayanan Kesehatan. 12: 94-101.

Kemenkes (2016). Hari Ginjal Sedunia 2016: Cegah Nefropati Sejak Dini. Available at: http://www.Kemenkes.go.id/article/print/16031000001/hari-ginjal-sedunia-2016-cegahnefropati-sejak-dini.html (Accessed: 27 September 2016).

Kerber KJ, de Graft-Johnson JE, Bhutta ZA, Okong P, Starrs A, Lawn JE (2007). Continuum Of Care For Maternal, Newborn, And Child Health: from slogan to service delivery. Lancet 370: 1358-69.

Kompas (2015). Penyakit Gerogoti Ekonomi. Available at: http://print.kompas.com/baca/sains/kesehatan/2 015/05/20/Penyakit-Gerogoti-Ekonomi (Accessed: 27 September 2016).

Kornblith H (2001). Epistemology: Internalism and externalism. Oxford: Blackwell.

Kotler P, Gary A (2011). Principles of Marketing, PT. Indeks-Prentice Hall, Jakarta.

Kotler, Philip, Kevin LK (2009). Manajemen Pemasaran, edisi 13, Penerbit : Erlangga , Jakarta.

Lucas, David (1995). Pengantar Kependudukan. Gadjah Mada University.

Moskowitz GB, Skurnik I (1999). Contrast effects as determined by the type of prime: Trait versus exemplar primes initiate processing strategies that differ in how accessible constructs are used. Journal of Personality and Social Psychology 76: 911-927.

Murti B (2013). Desain dan Ukuran Sampel Untuk Penelitian Kuantitatif dan Kualitatif di Bidang Kesehatan. Yogyakarta : Gadjah Mada University Press.

Nerenz (2005). "Health Care Organizations' Use Of Race/ Ethnicity Data to Add- 
ress Quality Disparities", Health affairs 24(2): 409-16.

Oliver EA, Okoroh JS, Chia V, DharmawadeneML, Riviello R (2014). 'Strengthening Health Systems Of Developing Countries: A Systematic Review of Surgery in Universal Health Coverage in Low-And Middle-Income Countries (Lmics)', Journal of the American College of Surgeons, 219(4): e42-e43. doi:10.1016/j.jamcollsurg.2014.07.497 Pallutturi, Sukri (2005). Ekonomi Kesehatan. Penerbit: Bagian Administrasi dan Kebijakan Kesehatan FKM UNHAS

Patel M, Liang LP, Hou H, Williams BB, Kmiec M, Swartz HM, Fessel JP, Roberts LJ (2008). Seizure-induced formation of isofurans: novel products of lipid peroxidation whose formation is positively modulated by oxygen tension. J Neurochem 104: 264-270.

PDPERSI (2016).Kasus Ginjal Peringkat 3 BPJS, Pemicunya Perilaku Tak Sehat. Availableat:http://www.pdpersi.co.id / content/news.php?mid=\&catid=23\& nid=2225 (Accessed: 27 September 2016).

Peters DH, Garg A, Bloom G, Walker DG, Brieger WR, Hafizur Rahman $M$ (2008). Poverty and Access to Health Care in Developing Countries. Annals of the New York Academy of Sciences 1136(1):161-171. doi:10.1196/annals.1425.011.
Raharjo P (2016). 'The Implementation Of Health Insurance By Social Security Agency (Bpjs)', International Journal Of Advanced Research 4(4):480-488. doi: 10.21474/ijaro1/315.

Ramirez SP (2011). The Relationship Between Religious Coping, Psychological Distress and Quality of Life in Hemodialysis Patien. Journal of Psychosomatic Research 72:129-135.

Rattu P (2015).Perbedaan Kualitas Pelayanan Keperawatan Terhadap Pasien Penerima Bantuan Iuran Dan Pasien Bukan Penerima Bantuan Iuran.

Robertson J, Smith A, Forzley M (2013). 'Legislation An Essential Tool For Ensuring Access To Medicines Policy Goals', WHO South-East Asia Journal of Public Health 2(1):69.doi:10.4103 /2224-3151.115848.

Saryono, Anggraeni (2013). Metodologi Penelitian Kualitatif dan Kuantitatif. Yogyakarta: Nuha Medika.

Suroto (1992). Strategi Pembangunan dan Perencanaa Kesempatan Kerja. Gadjah Mada University.

Tnp2k (2016) Program Jaminan Kesehatan Nasional (JKN)-Klaster I-Tanya Jawab: Tim Nasional Percepatan Penanggulangan Kemiskinan. Available at: http://www.tnp2k.go.id/id/tanyajawab/klaster-i/program-jaminankesehatan-nasional-jkn/(Accessed: 23 September 2016). 